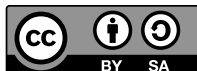

\author{
Sabina Jelenc Krašovec, Željka Bosanac, Sara Dalila Hočevar, \\ Neža Vrhovec, Nuša Zankolič, Sonja Kump ${ }^{1}$
}

\title{
COMMUINITY MEMBERS’ INITIATIVES IN PUBLIC OPEN SPACES: TWO CASE STUDIES FROM SLOVENIA
}

\begin{abstract}
The paper deals with public spaces as open, everyday arenas where people share experiences beyond their immediate circle of friends, family and age group. Public space is understood as a forum for social and personal change (Harvey, 2011; Lefebvre, 2013; Arendt, 1996; Habermas, 1989; 2001). Questions are analysed from the point of view of community members, who are strongly attached to the space and who are interested in belonging and in proactive changes in their living environment (Iecovich, 2014; Kohn 2004; Mean and Tims, 2005). The paper is based on the presumptions that public space has an important role in generating ideas and activities of community members and that it is an important venue for community members' informal learning. Ethnomethodological research in two public spaces (the Tabor community in Ljubljana and a small community in the coastal town of Izola) show that there are differences between both public spaces regarding top-down initiatives and bottom-up, self-organized activities. However, although the activity initiators were in one case different associations rooted in the community, and in the other the local people themselves, most of the activities were conducted by people living in the selected communities/public spaces themselves as is typical of grassroots activities. It was confirmed that learning was not often mentioned by members of either community and was mostly a hidden activity, resulting in tacit knowledge.
\end{abstract}

Sabina Jelenc Krašovec, PhD, Assoc. Prof., University of Ljubljana, Faculty of Arts, sabina.jelenc@guest.arnes.si

Željka Bosanac, zeljka.bosanac@gmail.com

Sara Dalila Hočevar, dalilcy@gmail.com

NežaVrhovec,nezyvrhovec@gmail.com

Nuša Zankolič,nusa.zankolic@gmail.com

Sonja Kump, PhD, Full Prof., University of Ljubljana, Faculty of Arts, sonja.kump@guest.arnes.si

1 The research was conducted by MA students of Andragogy for the purpose of experimental etnomethodological research. The findings were later presented at the ESREA network conference 'Between Global and Local', which was held in Ljubljana in June 2015. The research was conducted under the mentorship of Assoc. Prof. Sabina Jelenc Krašovec and Prof. Sonja Kump. 
Keywords: public open space, participation in community, top-down and bottom-up approach, informal learning in community

\section{INICIATIVE ČLANOV SKUPNOSTI V JAVNIH ODPRTIH PROSTORIH: DVE ŠTUDIJI PRIMERA IZ SLOVENIJE - POVZETEK}

$V$ prispevku se ukvarjamo z odprtim javnim prostorom, z vsakdanjimi prizorišči, kjer ljudje delijo svoje izkušnje zunaj najožje skupine prijateljev, družine in starostne skupine. Javni prostor razumemo kot forum za družbeno in osebno spreminjanje (Harvey, 2011; Lefebvre, 2013; Arendt, 1996; Habermas, 1989, 2001). Vprašanja analiziramo z vidika članov skupnosti, ki so tesno povezani s prostorom in ki jih zanimajo pripadnost in proaktivne spremembe njihovega življenjskega okolja (Iecovich, 2014; Kohn, 2004; Mean and Tims, 2005). Članek temelji na predpostavki, da ima javni prostor pomembno vlogo v tvorjenju idej in dejavnosti članov skupnosti ter za njihovo priložnostno učenje.

Etnometodološko raziskovanje dveh javnih prostorov (skupnosti Tabor v Ljubljani in majhne skupnosti $v$ obmorskem kraju Izola) kaže, da med tema javnima prostoroma obstajajo razlike glede iniciativ od zgoraj navzdol in od spodaj navzgor kot samoorganiziranih dejavnosti. A čeprav so bili organizatorji dejavnosti v enem primeru različne skupnostne organizacije in $v$ drugem ljudje kot posamezniki, so večino dejavnosti izvajali ljudje sami, tisti, ki so živeli v teh skupnostih. Potrdimo lahko, da člani nobene od skupnosti učenja večinoma niso omenjali, tako da je šlo najpogosteje za prikrito dejavnost, ki se je izražala $v$ skritem znanju.

Ključne besede: javni odprti prostor, sodelovanje v skupnosti, pristop od zgoraj navzdol in od spodaj navzgor, priložnostno učenje v skupnosti

\section{INTRODUCTION}

\section{Meaning of public open space for participation and learning in community}

Public open spaces are everyday arenas where people share experiences beyond their immediate circle of friends, family and age group. We argue that people co-create these spaces with their initiatives, ideas, actions and solidarity; among those activities, informal learning has an important role, although it is often hidden and unconscious.

Harvey (2011, pp. 173-174) defines public open spaces in three ways: as absolute space, which is unchangeable and static, in a social sense this is the exclusive space of private property; secondly, as relative space, which is defined as the space of processes and movement and is measured by distances in this space; and thirdly, as relational space, where processes form their own space and time (the concept of 'spacetime'). In this paper we will deal with space as relational space, created by everybody included, where identity becomes open, changeable, multiple and indefinite. Harvey believes that space is defined by human practice relating to space. Conflicts among different groups arise in absolute space and time, but relations among them become real in the non-material relational spacetime where they meet. He ascertains that relational space is 'nobody's land', created by everybody included. Space is defined by human practice relating to space. 
Areas traditionally deemed public open spaces include high streets, street markets, parks, playgrounds and allotments, which provide the necessary bandwidth for the flow of information among people. What is meant is the spaces where people can learn who they live with, and if the space is open enough, what people think and dream of; however, the 'public sphere' is different from the private domain of 'love, friendship and personal connection' and from the market domain of 'buying and selling' (Marquand, 2004 in Biesta and Cowell, 2012, p. 49). Between public open spaces and private, controlled spaces (homes, company offices) are privately owned social spaces which mix aspects of both public and private spaces (shopping centres, arts centres, car boot sales, markets etc.) (Kohn, 2004). Many of these look very much like conventional public spaces, but each carries a different set of expectations and obligations with implicit or explicit limits on who can use it and for what reason. These processes are defined as the progressive (radical) privatisation of public space, where everybody is attached to this subjectivity and which brings alienation and the disappearance of a common world. In a social space people are encouraged to congregate and interact, but subject to various limits and regulations. In this sense it is necessary to stress that particularly when a space becomes 'private', its possibility to be used by all groups becomes limited for undesired groups/persons, possibly found unacceptable due to their practices of using this space. If the space comes under exaggerated surveillance, some groups might not be accepted. Some communities build a bordered absolute space with certain rules of social participation, where the line between progressive communitarian policy and exclusionary and authoritarian practices can sometimes be very thin (privileged and underprivileged people; protection of spaces, bodies and property, even collectively, for example, in secure neighbourhoods). It is important how people understand space and time - are they victims of it or active creators of relative and relational space?

Arendt (1996) speaks about public space as a condition of politics and as a space which enables the political; as a common world, public space brings human beings together, and at the same time prevents their mutual destruction. By sharing experience with people beyond their immediate circle of friends, family and work colleagues on a daily basis, people collectively define what public interest is to be (Mean and Tims, 2005, p. 16).

Phenomenological and ethnomethodological research helps to understand learning processes through communication in public (open) spaces, where social structures, cultural meanings and values are understood as products of social interaction and communication. Habermas (Habermas, 1989; 2001, p. XI) puts the question of communication at the core of his theoretical model of society, which is based on the theory of communicative action. $\mathrm{He}$ connects the individual observer, actor and speaker with other observers, actors and speakers in the field of intersubjectivity, which explains how the participants' interaction with one another gives rise to their mutual interpretations of social situations. An individual is in fact not isolated but is instead involved in interpersonal relations in which he/she is defined as a personality and actively participates as a subject. Public space in this sense is an inner space where people follow their interests ('inter-est') and which only disappears 
when people establishing it disappear, and when activities which define the space stop (Arendt, 1996, p. 189, pp. 210-211). Public open spaces, filled with diverse people and uncontrolled events, therefore provide communicative and learning experiences forcing us to move beyond the self and to consider the plight of the other. Defence of public space in the name of social good through the fostering of mutual cooperation and learning, and exchange of ideas and knowledge is crucial; we agree that public open space is a forum for social and personal change, i.e., a 'transitional space' (Bourgeois, 2002; Wildemeersch, 2012). It is a system of relations that arises from acting, speaking and learning; as Torres (2013, p. 62) ascertains, through public space, people fight for recognition, social justice, the spirit of solidarity, and individual and collective well-being. They defend the principle of citizenship education and learning instead of the principle of consumerism.

The learning process in public spaces is linked to self-reflection, perspective transformation and a chance to address community problems by using the public space as an environment in which to struggle freely against all forms of regulation and control. Educational environments in educational institutions emphasise the notion of power, prescribed goals and authoritarian relations (Torres, 2013, p. 26), but learning in public spaces is emancipatory, democratic, civic and bottom-up. Learning interaction in public spaces, as compared to traditional (structured, regulated) learning environments, is changeable, open and formed by citizens through discussion; learning is unpredictable, multi-layered, and in a way more demanding, because its course and results are dependent on a participant's skills to perform it. Hence, such learning is natural, experiential and based on the problems of the citizens. Therefore such learning: a) can have an extremely important emancipating role; b) can encourage adults to retain control over their own lives and possibilities; c) can be empowering, transformative, liberating and transitional (Torres, 2013; McLaren, 2000; etc.); d) has the potential to be an activity for the development of critical consciousness (Freire, 1970; 1994), contributing to the empowerment of community members. To be a part of the speaking and acting process in public spaces, one has to have the will, desire and certain skills which can be learned only through the democratic process itself. Learning experiences in a public space are not always comfortable or joyful; they can be defined by hesitation, disjunction, discontinuity and conflict between participants (Wildemersch, 2012).

The skills of interaction with others are very much needed in negotiations and in conducting dialogue; they enable the translation of private issues/interests into public/common concerns. In the neighbourhood citizens mix and learn from and through this diversity. Mezirow (1997) stresses that transformative learning can take several forms involving either objective or subjective reframing ${ }^{2}$. It is rooted in the way human beings communicate and is a common learning experience which involves learning to make "our own

2 A frame od reference includes cognitive, conative and emotional components and encompasses 'habits of mind' and 'points of view'. Habits of mind become articulated in a specific point of view - with the development of values, beliefs, attitudes and feelings (Mezirow, 1997, p. 6). The aim is to become critically reflective about self-oriented and collective actions. 
interpretations rather than act on the purposes, beliefs, judgments, and feelings of others" (Mezirow, 1997, p. 5). As mentioned, a social context marked by trust is needed which enables dialogue and reflective discourse, (Mezirow, 2000); if circumstances are favourable, these goals could be realised by learning in public open spaces. Such learning gives us a voice, and consequently, helps us construct the meaning of the world for ourselves (Dirkx, 1998). This could be, by definition, at the core of learning in public spaces, which are open, unstructured, free spaces.

In this paper we analyse the use, co-creation of and learning in two public spaces in different towns in Slovenia: in the Tabor community, located in one of the neighbourhoods in Slovenia's capital city Ljubljana, and a small community, i.e., a street, in the coastal Slovenian town of Izola. The purpose of the research is to establish the similarities and differences between the two selected public spaces regarding: i) the users/participants of both public spaces ii) the origin of the initiatives leading to actions and/or the organization of activities; iii) the kinds of actions, initiatives, events taking place; iv) the relations between participants in the public space; v) the environmental influence on the 'atmosphere' in the public space; vi) the role of acting, speaking and learning and their perception by participants in the public spaces. We expected that differences would appear between revitalisation processes in a big and a small town regarding top-down vs. bottom-up initiatives. Another presumption was that in a big town the activities might include organised educational activities but that in a small town mostly informal learning would take place. The research was a snapshot of two public spaces at a certain time.

\section{RESEARCH AND FINDINGS}

\section{Methodology}

To analyse two different public spaces and the activities of the participants in those public spaces, we conducted ethnomethodological research. As is often stressed, ethnographic research as a specific form of qualitative inquiry is not a uniform approach (Hammersley, 2006; Larrson, 2006) and its dimensions depend on the kinds of methods employed. As 'a form of social and educational research that emphasises the importance of studying at first hand what people do and say in particular contexts' (Hammersley, 2006, p. 4), our ethnographic research included two case studies and we conducted active participation, open (uncovered) observation and interviewing. Initially the main goal was to develop understanding of people's perspectives through the study of various documents about selected communities; however, later research was based particularly on participant observation in relevant settings, personal discussions with members of the communities and four open-ended interviews.

According to the general idea developed by Garfinkel, we as a first step observed and analysed everyday activities to find out how people make sense of 'potentially ad hoc collocations of scenic features that make up everyday situated activities' (Garfinkel, 1996 in Freebody and Freiberg, 2011, p. 80). Our observation was focused on living and learning 
in two selected public spaces: the Tabor community, located in one of the neighbourhoods in Slovenia's capital city Ljubljana, and a street (a defined, bordered public space) in the coastal town of Izola. We built on the premise that social life is the outcome of the joint effort of members of a society as they engage in it and work alone or with others to make sense of their everyday activities with and for others (Muršič, 2011). As researchers we were part of the public space and we observed life, actions, communication, learning, and cooperation of the participants in the selected public spaces.

Later we conducted non-structured interviews in both selected public open spaces in Ljubljana and in Izola: in Tabor we conducted interviews with two activists and initiators of social activities in the neighbourhood, an activist in the Tabor Cultural Quarter Association (Društvo kulturna četrt Tabor - KČT) and an activist in the Prostorož cultural association $^{3}$, and in Izola with two active participants in the public space (one was the head of the Association of Izola People, and the other an active cultural worker living in Ljubljana Street, also one of the initiators of social actions in this area). The observation lasted the whole academic year 2014-15 in Tabor but was focused on April and May 2015 in Izola. The interviews were conducted between 17 and 20 April 2015. All in all, the research directly and indirectly involved more than 100 people (depending on how many citizens took part in different activities and events).

We used an open coding system, but in later stages the gathered research material was structured according to the main interest categories. The research result was a story based on the understanding of the life-stories and happenings in social context (Atkinson, 1992). We tried to understand the deeper social forces that operated in these settings and to analyse what in these stories influenced the relations and cooperation among the participants in the selected public spaces, their actions and results.

\section{Short descriptions of selected public spaces}

\section{Tabor (Ljubljana)}

The Tabor neighbourhood is one of the town quarters in Ljubljana. There was a tendency of decline of the community momentum in the neighbourhood. The Tabor Cultural Quarter Association (Društvo kulturna četrt Tabor - KČT) was established on 1 March 2001 to foster culture, education and sports activities for the local population, to promote sustainable development and to solve the spatial problems of the neighbourhood, but mainly to foster connections between individuals and organizations in the Tabor neighbourhood and their participation. In the year 2012 additional organizations joined the Tabor initiative and they now act in the framework of Tabor Cultural Quarter Association. KČT and other organizations are using cultural content to connect the neighbourhood, which many of local residents considered to be transient and grey. The initiators of KČT activities do not see the neighbourhood as a degraded space which needs urgent intervention, instead recognising it as a space for action which can still be improved. Individuals with their own

3 For description cf. Footnote 2. 
specific backgrounds and experience have already started working out the solutions to problems which the local inhabitants consider critical and in need of improvement. With this in view, many different projects have been initiated. With the help of spatial intervention and numerous events, Tabor Park has regained its lively character.

\section{Ljubljana Street (Izola)}

Ljubljana Street is located in the old Mediterranean town of Izola, which lies on the southwest shore of the Gulf of Trieste, where the ancient traditions of fishing and winemaking, mysterious traces of the past, and the welcoming character of the locals merge together to form an unforgettable mosaic of experiences. The Association of Izola People organizes a number of activities, events and exhibitions in Ljubljana Street aimed at locals, random walk-ins and tourists. The Association of Izola People keeps a gallery called Plac Izolanov, which is located in Ljubljana Street. The gallery is a small but valuable space which is actually "an extension of the street with a roof" and where various exhibitions and other performances take place. The locals in a nearby bar help to manage and take care of several exhibitions. Many cultural and social events take place in Ljubljana Street known as "Largo pr' Spini". Throughout the year locals host free live concerts here. Ljubljana Street is also well-known for its street garden with many types of basil. Each year the 'Association of Izola People' organizes the traditional "Bazilikjada", where visitors can taste a variety of dishes with basil prepared by local chefs and caterers. In 2015, when the research was conducted, the seventh Bazilikjada was held, on its way to becoming one of the most recognisable ethno-culinary events in Izola.

\section{Findings and discussion}

\section{Initiatives for activities in selected public spaces - Tabor (Ljubljana) and Ljubljanska Street (Izola)}

The initiative for the revitalization of the Tabor neighbourhood in Ljubljana came from the non-profit cultural organization Bunker. In order to find out about the needs and wishes of the locals regarding the revitalization of their neighbourhood, Bunker activists conducted sociological research with community members. The findings showed that the identity of the Tabor neighbourhood was being lost. Inspired by their sense of social responsibility, they reached out to other cultural, artistic and educational organizations located in Tabor to discuss how to revitalize the neighbourhood. From the very beginning, Bunker tried to pass on the initiative and the organization of events to other local organizations, like ProstoRož ${ }^{4}$, which eventually coordinated bigger events, such as garage sales, and organized activities in frequent contact with the inhabitants. Afterwards ProstoRož passed on most of the Tabor neighbourhood events to the Tabor Sports Society, which is also located in the neighbourhood and is the owner of Tabor Park.

4 Prostorož is a cultural association based in Tabor and active in the field of public urban space. They believe that public spaces should be open to everybody, and in ten years of activities they have conducted more than 50 projects (for more see: http://prostoroz.org/) 
Unlike the Tabor neighbourhood in Ljubljana, the initiative for the revitalization of Ljubljana Street in Izola came from active local people who were willing to do something socially valuable themselves. They spontaneously gathered in an informal way and started to organize various self-initiated activities within a small community where everybody knows each other. The main initiators were cultural workers, intellectuals, and musicians, who created a critical mass and consequently included other neighbours. When asked how to attract neighbours to participate in revitalizing their street or neighbourhood, they simply state:

„Go to the nearest café for some coffee and simply talk about your street/neighbourhood. The greatest value of life is living in community."

\section{Activities in Tabor and Ljubljana Street}

The initiators of activities in Tabor NGO Zavod Bunker detected a number of needs in the neighbourhood such as a desire for more public green spaces, lack of parking places, and a wish to have a swimming pool, bicycle tracks, and more activities that would make their neighbourhood alive. Although the revitalisation initiative came from the organization (top-down), it was based on the needs and wishes of community members. One of the initiators of the revitalization of the Tabor neighbourhood emphasizes:

„Bunker cannot solve all the problems and grant all the wishes, so we asked ourselves a question: Which are the problems that we can solve? A couple of these quickly became clear to us, like the lack of green surfaces. So together with another association (KUD Obrat) we started the project „Beyond the Construction Site“, a community garden for temporary use of land."

The citizens of Ljubljana Street in Izola also had a tradition of living by the saying each for himself". The change appeared some decades ago when immigrants from Bosnia came to Izola in search of work; they brought with them their authentic culture of socializing with neighbours. The present initiators of activities also moved to Ljubljana Street (Izola) from other parts of Slovenia and were welcomed by this hospitable neighbourhood. A group of cultural workers started the initiatives to bring more life to Ljubljana Street and revitalize it with various activities. They generally live according to this social outlook:

'As human beings, we have a need for socializing with others. As people, we need other people to comfort us, help us when in need.'

In order to discover the needs of their neighbours, the activity initiators just listened to them and observed them on a daily basis. They talked to each other spontaneously and everyone could express themselves. This is in congruence with Habermas's (1989) ideas of communicative action through which participants interact in social and interpersonal situations and where people follow their interests ('inter-est') (Arendt, 1996, p. 189, 
p. 210-211) and define the space. As a result, visitors keep coming back to socialize and nurture friendships. They describe this immigration phenomenon with the following metaphor:

„As you know, just like the river does not stop at the narrows but continues to flow, in the same way people don't stick around and connect with others in an inconvenient place, but in the space where the river spreads and consequently moves slower. It is the same with people who slow down their speed of movement and enjoy spontaneity in a comfortable environment. "

To revitalize open public spaces there are many activities offered throughout the year in the Tabor neighbourhood (Ljubljana) and in Ljubljana Street in Izola. The activities in Tabor are as follows: slackline, fencing, yoga, thai chi, film screenings, free concerts, garage sales, and a celebration of the international „Neighbour Day“. On „Neighbour Day“ citizens ,open their doors“ and organize activities for others, for example making a photo exhibition, cooking dinner for others, planting flowers, working with clay, reading poetry etc. More than 30 activities take place in Tabor during the celebration of „Neighbour Day“.

As mentioned before, there are also many activities organized in Izola, in Ljubljana Street. Some of these activities are organized with the aim of celebrating various thematic events such as the Coffeeshop Feast, Briscoliad (a card game), 'Šalšijada' (making tomato sauce in the street), a competition in making 'golaž' (a spicy dish originally from Hungary), various concerts, photo, art and other exhibitions, lectures, storytelling for children, making tea in public, Bingo, etc. The most visited is the „Basil Feast“. The organizers buy more than 25 different kinds of basil, the neighbours plant them in pots in Ljubljana Street. Many people participate in cooking more than 50 kinds of basil dishes. The event is public and passers-by are welcome to taste the dishes.

In some cases, the performers of different activities in the Tabor neighbourhood (Ljubljana) are hired professionals, like musicians and technicians, but despite the initiative coming from Bunker, most often the activities (such as yoga, poetry reading or thai chi) are run by the locals themselves who want to share their knowledge with their neighbours. Similarly, activities in Ljubljana Street (Izola) are performed by the initiators (community members) themselves (like the "Silk Road" association, whose members monthly cook food from different parts of the world and share it with neighbours and passers-by) and by various invited Slovenian musicians. The organizers of Ljubljana Street events emphasize:

"Everybody takes care of the activities they know and are good at."

It is important to stress that as a result, the above mentioned interventions in public open spaces in Tabor and Ljubljana Street (Izola) influence the architecture in the community. In Tabor, there has been partial regulation of traffic arrangements, the painting of a street 
with local Tabor kindergarten children, and a community garden project "Beyond the Construction Site", which allows neighbours to temporarily use the land for planting. In Izola, in 2014 the local authorities wanted to remove all of the basil pots and build concrete sinks instead. The idea was to make the town 'super modern'. Ljubljana Street residents organized themselves and successfully rejected this intervention unlike other residents of nearby streets in Izola, who had no such will and intention. This is how Ljubljana Street locals emphasize the importance of this process:

"It would be strange for us, as those sharp shapes of concrete sinks do not suit the street which has an old-time homely, Mediterranean spirit. It is not necessary for every public space to be 'super modern'."

We can confirm that 'skills of civility', as defined by Bauman (2002), are necessary for acting and speaking in a public space, but they are difficult to learn and preserve. Interaction with other citizens and local authorities is very much needed for negotiations and conducting dialogue; they enable the translation of private issues/interests into public/ common concerns. In the neighbourhood, we mix daily with others who do not necessarily speak the same language and share the same memory or history; from this and through this, we learn (Bauman, 2005, p. 23). The learning process therefore includes evaluation of individuals' knowledge, values, desires, dreams and its transformation and reformulation according to collective goals and concerns.

To be part of the speaking and acting process in public spaces, one has to have the will, desire and certain skills which can only be learned through the democratic process itself. Learning experiences in a public space are not always comfortable or joyful; they can be defined by hesitation, disjunction, discontinuity and conflict between participants (Wildemersch, 2012). In our research, the participants in the community activities in the Tabor neighbourhood are not just local residents but also people who come from different parts of Ljubljana. They are a heterogeneous group, including older people from a local home for the elderly, children from local kindergartens, passers-by and people who have intentionally come to attend some of the events. Similarly, participants who attend events in Ljubljana Street (Izola) are diverse, for Izola is known as a multicultural city with members from at least 12 different cultures.

\section{Informing about activities in Tabor and Ljubljana Street}

Information about events in the Tabor neighbourhood (Ljubljana) is shared with neighbours through the use of various channels: distributing flyers and written invitations, e-mail, Facebook and Newsletter, whereas local organizations are informed via regular meetings. Some effective ways of spreading information include an info board located in Tabor Park (the central happening area) and a zoetrope (a spinning wheel with printed copies of the event programme in it), but also mouth to mouth. Particularly the latter applies to Ljubljana Street, too, in addition to information conveyed through the local magazine Mandrač, a tourist agency and online. 


\section{Problems and barriers in the process of conducting activities}

The Tabor neighbourhood has a negative connotation because of the vicinity of a methadone centre and Metelkova City, an autonomous social centre. After partying in Metelkova, young people regularly come to Tabor Park and organize their own after-parties. The local residents are reluctant to undertake spatial interventions in the park due to their worries that this would consequently invite even more drug addicts to the area. As Harvey (2011, p.174) ascertains, relational space is 'nobody's land', created by everybody included and should be inclusive and open. But our research shows that community members can also be exclusive to some groups; they want to preserve peace and quiet and are not ready to 'open' the space to 'different' youngsters. They are not ready to think about alternative solutions and possibilities to face these issues constructively.

Additionally, the organizers of Tabor events faced some problems with the legal owners of Tabor Park during the first period of their initiatives. One specific problem was the political and bureaucratic system which slowed down the process of event realization.

When looking at the situation in Ljubljana Street in Izola, we see a marked difference; in Izola no notable barriers appeared as their only responsibility with regard to the local authorities is to preserve order and cleanliness of the public space in Ljubljana Street.

\section{Financial support and cooperation with local authorities}

Events in the Tabor neighbourhood are financially supported by local, national and European funds. They also include volunteer work when organizing various cleaning and work activities. For example, the municipality of Ljubljana funded the construction of a children's playground, which was an example of positive cooperation with Ljubljana local authorities. However, the perception of Tabor activists is that the local government has been generally unresponsive, as year after year they are receiving fewer and fewer funds for their activities.

On the other hand, Ljubljana Street activities in Izola were not financed by the local authorities until the Society of Izola Residents in 2002 was founded. Since then, some of their basic expenses have been covered. But when the authorities tried to install stone benches in Ljubljana Street as a part of the 'urban renovation' of Izola, the socially active residents of Ljubljana Street gathered more than 320 signatures against it and consequently stopped the project from being executed in Ljubljana Street. The neighbours emphasize:

"Politicians often suggest some activities to be performed in Ljubljana Street with the aim of becoming profit-oriented tourist events. We don't want it and we don't support it. “

There are obvious differences between bottom-up, self-organized activities and top-down initiatives. When people are organizing events out of their own initiative and on a smaller scale, they are ready to invest their energy, ideas and also some funds. In the case of outside initiatives, people do not identify enough with the suggested ideas for community actions and they are not as proactive as they could be. This entails a bigger need for money 
and some external incentives. If Tabor inhabitants took initiative to make changes, the situation would be different. Such examples include self-organized local/district communities in Maribor, where citizens of a big city organize civic actions on their own, without external incentives (Gregorčič and Jelenc Krašovec, 2016).

\section{Experiences and knowledge acquired in selected public spaces}

The organizers of Tabor events, such as the association ProstoRož, educate students, individuals and groups active in their local environment with the intention of activating and motivating such groups and individuals to transfer their knowledge based on accumulated experience. They also connect with other organizations in their local environment in order to learn from each other. An activist from Zavod Bunker emphasizes:

"Education is a side effect of the fact that we want to offer cultural content and make it publicly accessible. We organize lectures and conferences in the area of art and education."

The influence of the initiatives in Ljubljana Street in Izola on the wider society is smaller than in Tabor; they mostly connect neighbours from nearby streets who support each other's events. There are hardly any educational activities, but it seems considerable informal learning is happening through their social activities. This is mostly un-conscious and un-intentional learning, happening while preparing basil dishes, learning how to organize various events, communicating with invited cultural workers, etc. Schugurensky (2000) conceptualises informal learning as a residual category for learning activities, including self-directed learning, incidental learning and socialization. In Ljubljana Street we can observe self-directed learning (learning how to prepare dishes, how to plant herbs, etc., which is intentional and conscious), considerable incidental learning (learning by participating in different events, which is unintentional but conscious), but also socialization as a change of values, attitudes, and dispositions (happening while coordinating events, discussing future actions, cooperating, opposing local authorities' decisions, which is mostly unintentional and unconscious) (Mündel and Schugurensky, 2008, p. 50). Most acquired knowledge is tacit but still important (Ličen, 2012; Schugurensky, 2006). Our research results confirm that it strongly influences the knowledge, skills, attitudes and values of people involved in such learning (Gregorčič and Jelenc Krašovec, 2016; Mündel and Schugurensky, 2008; Vrečer, 2014; Schugurensky, 2006; Foley, 2001).

\section{CONCLUSION}

The observation and analysis of two different public spaces offers interesting findings. Our presumption that people co-create public spaces with their initiatives, ideas, actions and solidarity is partially confirmed by our research, because many interpersonal relations developed and much cooperation took place; both public spaces could be defined as relational spaces (Harvey, 2011). We find that although the activity initiators were in 
one case different associations rooted in the community, and in the other the local people themselves, most activities were conducted by people living in these selected communities/public spaces, as is typical of grassroots activities. They were the main creators, fighters and negotiators in community activities, which particularly holds true for the selected public space in Izola.

We also find that in bigger communities public spaces are more difficult to revitalize only through the initiatives of local inhabitants; but in the case of Ljubljana Street in Izola, which is a very active small public open space, activities are bottom-up. In this case we can observe self-initiated activities giving power to members of community but at the same time showing openness also towards visitors and other people coming to their neighbourhood. The findings show that people appreciate community activities and are willing to participate in them, but they sometimes need a push or a launch to become active participants in the public space. Initiatives can come from above (from community associations) or from below, from members of community. In the latter case local community members are more strongly involved in the preparation and organization of activities; they are the necessary part of the link.

Even though the activities in the two communities were not oriented towards wider social changes, we can observe that self-organization is an important way of influencing the local community, but also changing personal mind frames (Mezirow, 1997). It can be argued (Biesta, 2012; Biesta and Cowell, 2012) that learning in a public sphere (space) could be defined as civic learning; it refers to the processes and practices of learning that are at stake in the public sphere and could be understood "in a way that strives for a single-voice consensus and in a way in which such learning processes remain tied to a democratic commitment to plurality and difference" (Bista and Cowell, 2012, p. 48).

As we expected from the beginning, learning is something which is hidden and its results are tacit (Schugurensky, 2006), which explains why it was not often mentioned by members of the two communities; however, the changes happening in both public open spaces would doubtless not have been possible without constant informal, mostly incidental learning. Because it is difficult to verbalize this, it is difficult to confirm and analyse its effects. However, Schugurensky (2006) stresses the importance of community meetings and activities as educational spaces or learning environments where citizens exchange experiences, socialize the difficulties and challenges, encounter and identify priorities, etc. This was obvious also in our research through their narratives that emphasised collaborative planning, sharing knowledge, internalizing the meaning of social actions, becoming empowered and therefore initiating new actions. Many actions involved community development activities and some social change; Foley (2001, pp. 71-72) defines this kind of learning as social, cultural and political. It can be maintained that learning happening through social activities is informal, authentic and experiential. It is focused on the connection of community members and the quality of their everyday lives. However, in Tabor there were also some organized educational activities, where they mentioned educating the wider public as an important part of cohabiting. 
We can confirm that the selected public spaces played a vital role in the social life of communities. However, the discussion of the importance of preserving the public space, resistance against the marketization and privatization of the space came to the forefront also in our research. Through the words and actions of our 'co-speakers' it becomes clear that actors in the public space should keep a distance from the market and the state, should avoid institutionalized ways of thinking about learning and education, and should preserve their critical stance towards political and economic influences. They have to show moral responsibility and political commitment to create a sphere of public debate, as suggested by Torres (2013, p. 79). These ideas are close to the theories on the role of public intellectuals which advocate autonomous learning, self-organisation of learning and open learning (Hall, 2012).

Finally we would like to stress the limitations of this research. First of all, the student-led research conducted in both public spaces was a learning process, which also holds true of the process of writing this article. We have learned a lot about communication in a team, cooperation and division of tasks, and particularly about field research and the abilities necessary to come close to the people living in the community. In a sense we have also conducted autoethnographic research, because our experiences were important in reflecting the data and connecting them with our perception. With this in view, we moved to Izola as a team for some time and tried to get in touch with the environment. The limitations of the study are mostly related to the learning process. To be able to say more about the informal learning happening in the selected public spaces, another study with a different instrument would be needed. This is something left to new generations of students to do.

\section{REFERENCES}

Arendt, H. (1996). Vita Activa. Ljubljana: Krtina.

Atkinson, P. (1992). Understanding ethnographic texts. Newbury Park, London, New Delhi: SAGE.

Bauman, Z. (2002). Tekoča moderna. Ljubljana: Založba /*cf.

Bauman, Z. (2005). Learning to Walk in Quicksand. In A. Bron, E. Kurantowicz, H. Salling Olesen, and L. West (Eds.), 'Old' and 'New' Worlds of Adult Learning (pp. 17-26). Wroclaw: Wydawnictwo Naukowe Dolnoslaskiej Szkoly Wyzszej Edukacji.

Biesta, G. (2012). Becoming public: Public pedagogy, citizenship and the public sphere. Social \& Cultural Geography, 13(7), 683-697.

Biesta, G. and Cowell, G. (2012). How is community done? Understanding civic learning through psychogeographical mapping. International Journal of Lifelong Education, 31(1), 47-61.

Bourgeois, E. (2002). A Constructivist Approach to Adult Learning. In A. Bron and M. Schemmann (Eds.), Social Science Theories in Adult Education Research (pp. 130-152). Münster: LIT Verlag.

Dirkx, J. M. (1998). Transformative Learning Theory in the Practice of Adult Education: An Overview. PAACE Journal of Lifelong Learning, 7, 1-14.

Freebody, P. and Freiberg. J. (2011). Ethnomethodological Research in Education and the Social Sciences: Studying 'the Business, identities and Cultures' of Classrooms. In L. Markauskaite, P. Freebody and J. Irwin (Eds.), Methodological Choice and Design. Scholarship, Policy and Practice in Social and Educational Research (pp. 79-92). Dordrecht, Heidelberg, London, New York: Springer. 
Freire, P. (1970). Pedagogy of the Oppressed. New York: Seabury Press.

Freire, P. (1994). Pedagogy of Hope. Reliving Pedagogy of the Oppressed. New York: Continuum.

Foley, G. (2001) Radical adult education and learning. International Journal of Lifelong Education, 20 (1-2), 71-88.

Gregorčič, M. and Jelenc Krašovec, S. (2016). Social and learning practices in participatory democracy process: The case study of self-organized communities in Maribor, Slovenia, contextualised through the e-participatory budgeting in Reykjavík, Iceland. Journal of Contemporary Educational Studies, 67(4), 168-182.

Habermas, J. (1989). Strukturne spremembe javnosti. Ljubljana: ŠKUC, Filozofska fakulteta.

Habermas, J. (2001). On the Pragmatics of Social Interaction. Preliminary Studies in the Theory of Communicative Action. Cambridge: The MIT Press.

Hall, B. L. (2012). A Giant Human Hashtag': Learning and the \#Occupy Movement. In B. Hall, D. E. Clover, J. Crowter and E. Scandrett (Eds.), Learning and Education for a Better World: The Role of Social Movements (pp. 127-139). Rotterdam: Sense Publishers.

Hammersley, M. (2006). Ethnography: problems and prospects. Ethnography and Education, 1(1), 3-14. DOI: $10.1080 / 17457820500512697$.

Harvey, D. (2011). Kozmopolitstvo in geografije svobode. Ljubljana: Sofia.

Iecovich, E. (2014). Aging in Place: From Theory to Practice. Anthropological Notebooks, 20(1), 21-33.

Kohn, M. (2004). Brave New Neighborhood: The Privatization of Public Space. New York, London: Routledge.

Larsson, S. (2006). Ethnography in action. How ethnography was established in Swedish educational research. Ethnography and Education, 1(2), 177-195.

Ličen, N. (2012). Model skupnosti prakse in situacijsko učenje. Andragoška spoznanja, 18(3), 10-24.

Lefebvre, H. (2013). Produkcija prostora. Ljubljana: Studia Humanitatis.

McLaren, P. (2000). Che Guevara, Paulo Freire, and the Pedagogy of Revolution. Maryland: Rowman $\&$ Littlefield.

Mean, M. and Tims, C. (2005). People make places. London: Demos.

Mezirow, J. (1997). Transformative Learning: Theory to Practice. In P. Cranton (Ed.), New directions for adult and continuing education: No. 74. Transformative learning in action: Insights from practice (pp. 5-12). San Francisco: Jossey-Bass.

Mezirow, J. (2000). Learning to think like an adult: Core concepts of transformation theory. In J. Mezirow and Associates (Eds.), Learning as transformation: Critical perspectives on a theory in progress (pp. 3-34). San Francisco: Jossey-Bass.

Mündel, K. and Schugurensky, D. (2008). Community based learning and civic engagement: Informal learning among adult volunteers in community organizations. New directions for adult and continuing education, 118, Summer.

Muršič, R. (2011). Metodologija preučevanja načinov življenja. Ljubljana: Filozofska fakulteta.

Schugurensky, D. (2000). The Forms of Informal learning: Towards a Conceptualisation of the Field. Retrieved from https://tspace.library.utoronto.ca/bitstream/1807/2733/2/19formsofinformal.pdf.

Schugurensky, D. (2006). Strategies to elicit informal learning and tacit knowledge: Methodological notes from the field. Retrieved from http://www.wallnetwork.ca/resources/SchugurenskyTacitKnowledge2006.pdf.

Torres, C. A. (2013). Political Sociology of Adult Education. Rotterdam/Boston/Taipei: Sense Publishers. Vrečer, N. (2014). "Druženje, vedoželjnost, širina”, učinki neformlanega izobraževanja odraslih v projektu BELL. Andragoška spoznanja, 20(3), 71-87. 
Wahl, H.W. and Oswald, F. (2013). Environmental Perspectives on Ageing. In D. Dale \& C. Phillipson (Eds.), Social Gerontology (pp. 111-124). London, Thousand Oaks, New Delhi, Singapore: Sage Publications.

Wildemeersch, D. (2012). Imagining pedagogy in public space: visions of cultural policies and practices in a city in transformation. International Journal of Lifelong Education, 31(1), 77-95. DOI: 10.1080/02601370.2011.636638. 